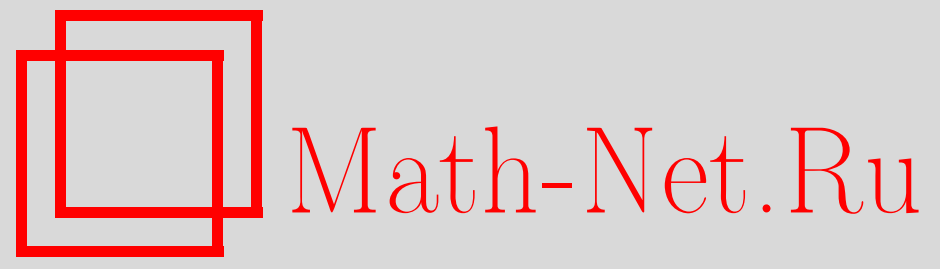

А. С. Холево, Международный симпозиум по теории информации 1998 г., Теория вероятн. и ее примен., 1998, том 43, выпуск 4, 823-824

DOI: https://doi.org/10.4213/tvp2174

Использование Общероссийского математического портала MathNet.Ru подразумевает, что вы прочитали и согласны с пользовательским соглашением

http: //www . mathnet.ru/rus/agreement

Параметры загрузки:

IP : 52.205 .19 .152

26 апреля 2023 г., 13:34:49

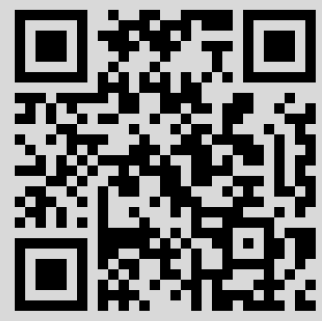




\section{МЕЖДУНАРОДНЫЙ СИМПОЗИУМ ПО ТЕОРИИ ИНФОРМАЦИИ 1998 Г.}

Международный симпозиум по теории информации, прошедший под знаком 50-летия опубликования основополагающей работы К. Шеннона «Математическая теория передачи информации», состоялся с 16 по 21 августа 1998 г. в Массачусетском технологическом институте (Кембридж, штат Массачусетс, США). Симпозиум был организован Обществом по теории информащии Института инженеров по радиоэлектронике (IEEE Infomrmation Theory Society) при финансовой поддержке NSF, NASA, Office of Naval Research, AT\&T, Motorola, Qualcomm.

Сопредседателями симпозиума были Д. Форни (D. Forney) и P. Галлагер (R. Gallager), программный комитет возглавляли В. Пур (V. Poor) и С. Верду (S. Verdú). Хотя симпозиумы по теории информации проводятся регулярно, настоящий выделяется из них по своему масштабу, организационному размаху и, видимо, по своему значению для последующего развития теории информации и смежных областей. Число участников симпозиума составило около 800 человек практически из всех научно развитых регионов мира. K сожалению, сам К. Шеннон не смог принять участие в симпозиуме из-за тяжелой болезни.

В первый день состоялась сессия, посвященная истории создания теории информации, в которой своими воспоминаниями поделились П. Элайэс (P. Elias) (председатель), С. Голомб (S. Golomb), А. Дж. Витерби (А. J. Viterbi), T. М. Ковер (Т. М. Cover), И. Чисар (I. Csiszár), Р. М. Фано (R. М. Fano), Д. А. Хаффман (D. A. Huffman), Дж. Л. Мэсси (J. L. Massey), Б. МакМиллан (В. McMillan), Дж. А. Миллер (J. А. Miller), М. С. Пинскер (M. S. Pinsker), Д. Слепян (D. Slepian), Дж. К. Вольф (J. K. Wolf) и Дж. Зив (J. Ziv).

Выступления воссоздали уникальную творческую атмосферу 50-х годов, которой нынешнее поколение ученых может только позавидовать. Надо сказать, что речь шла главным образом об исследованиях в США, хотя справедливо была отмечена и выдающаяся роль работ В. А. Котельникова, относящихся к тому же периоду. О влиянии идей $\mathrm{K}$. Шеннона на математику, в значительной мере стимулированному А. Н. Колмогоровым, говорил М. С. Пинскер. Прозвучала мысль, неоднократно находившая подтверждение в ходе симпозиума, что произошедшие на рубеже 40-50-х гг. теоретические открытия в области передачи информации, наряду с изобретением полупроводников, обозначили направление развития информационных технологий, и, в этом отношении, предопределили облик современного мира.

Каждый день проходило по одной пленарной лекции:

Л. Клейнрок (L. Kleinrock) (Калифорнийский университет) «Номадический компьютинг» (о синтезе современных мобильных средств связи и компьютинга);

T. Кайлат (Th. Kailath) (Стэнфордский университет) «От согласованных фильтров к мартингалам»;

И. М. Джекобс (I. M. Jacobs) (Qualcomm) «CDMA (каналы множественного доступа с разделением кодов) в войне и мире - от дуального модема к дуальному сетевому телефону»;

Н. И. А. Слоун (N. J. A. Sloan) (AT\&T) «Коды и решетки или проблема сферической упаковки» (шенноновская лекция); 
P. M. Kapп (R. M. Кагр) (Вашингтонский университет) «Вариации на тему 20 вопросов» (о задачах идентификации).

Секционные доклады были сгруппированы в 102 секции, по 6 параллельных секций (4-5 20-минутных докладов в каждой). Наряду с традиционной тематикой, возрастающее внимание было уделено быстро развивающимся перспективным направлениям, таким, как практические методы кодирования и декодирования, впервые позволившие приблизиться к шенноновской пропускной способности (турбо-коды), каналы с множественным доступом и сети, теория сложности и криптография, квантовая теория информации. Таким образом, было наглядно продемонстрировано, что и после первых 50 лет, теория информации представляет собой динамично развивающуюся научную дисциплину, не только ищущую и находящую ответы на актуальные проблемы научно-технического прогресса, но и активно влияющую на его направление.

По традиции, состоялось вручение целого ряда премий, на этот раз дополненных специально приуроченными к золотому юбилею премиями за научную статью и за технологическое усовершенствование. Премия IEEE им. К. Кобаяси (K. Kobayashi) была присуждена Дж. К. Вольфу за фундаментальный вклад в коммуникации множественного пользования и технологию магнитных запоминающих устройств. Премия IEEE им. Джудит Резник (Judith Resnick) (женщина-космонавт, погибшая при взрыве американского космического корабля «Шаттл» в 1996 г.) О. М. Коллинзу (O. M. Collins) за разработку методов кодирования в космической связи, способствовавших успеху миссии «Галилей» (передача на Землю фотографий спутников Юпитера).

Каждый зарегистрированный участник симпозиума получил 500-страничный том с тезисами докладов, копию работы K. Шеннона и комплект CD-ROM с полным содержанием журнала IEEE Transactions (1953-1997 гг.)

A. С. Холево 